
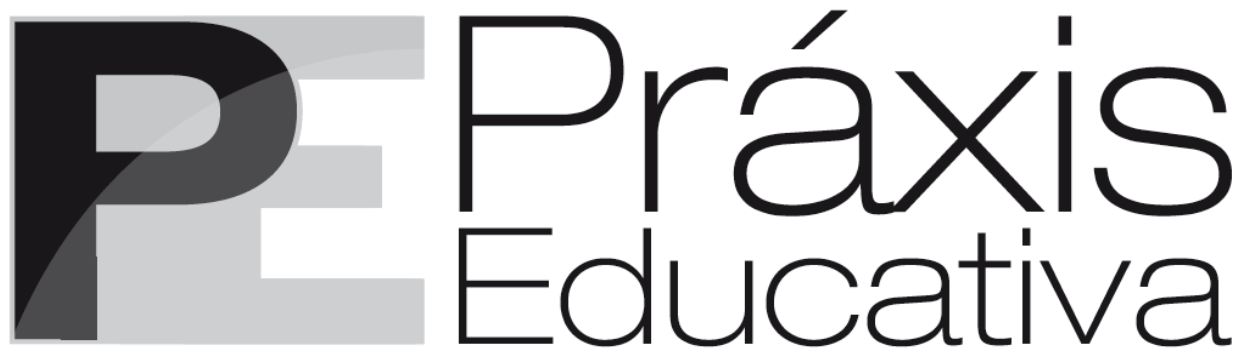

ISSN 1809-4031

elSSN 1809-4309

https://doi.org/10.5212/PraxEduc.v.16.17770.060

\title{
O ensino da escrita alfabética nos critérios de avaliação do PNLD (1998- 2016): Que conhecimentos e habilidades eram contemplados?*
}

\section{Teaching of alphabetical writing in the PNLD evaluation criteria (1998- 2016): What knowledge and skills were contemplated?}

\section{La enseñanza de la escritura alfabética en los criterios de evaluación del PNLD (1998-2016): ¿Qué conocimientos y habilidades eran contemplados?}

\author{
Alexsandro da Silva ${ }^{* *}$ \\ https://orcid.org/0000-0002-1943-8227 \\ Artur Gomes de Morais ${ }^{* * *}$ \\ https://orcid.org/0000-0002-2325-0315
}

\begin{abstract}
Resumo: Este artigo apresenta resultados de um estudo que visou a analisar os critérios de avaliação de livros ou coleções de alfabetização, instituídos no período de 1998 a 2016, no âmbito do Programa Nacional do Livro Didático (PNLD). O foco foram os conhecimentos e as habilidades relativos ao sistema de escrita alfabética contemplados nesses critérios nos Guias de Livros Didáticos. Os resultados evidenciaram: as duas primeiras edições do Programa continham poucos critérios relativos a esse eixo de ensino, enquanto as seguintes apresentaram, progressivamente, uma ampliação do número e da variedade de critérios e de conhecimentos/habilidades avaliados. Concluiu-se que, inicialmente, pareceu existir certa contribuição do Programa para a "desinvenção da alfabetização" no Brasil, mas assistiu-se, a partir de 2010, a uma busca gradativa de maior conciliação entre o ensino do sistema de escrita e as práticas de leitura e produção de textos de diferentes gêneros escritos, na perspectiva de alfabetizar letrando.
\end{abstract}

Palavras-chave: Ensino da escrita alfabética. Livros de alfabetização. Avaliação de livros didáticos. PNLD.

Abstract: This article presents the results of a study that aimed to analyze the criteria for evaluating literacy books or collections, instituted between 1998 and 2016, within the scope of the Programa Nacional do Livro Didático - PNLD (National Program for Textbooks).The focus was on the knowledge and skills related to

\footnotetext{
* A pesquisa que deu origem a este artigo foi realizada com o apoio do Conselho Nacional de Desenvolvimento Científico e Tecnológico (CNPq) - Brasil e da Fundação de Amparo à Ciência e Tecnologia do Estado de Pernambuco (FACEPE) - Brasil.

** Professor da Universidade Federal de Pernambuco (UFPE). Doutor em Educação. E-mail: <alexsandro.silva2@ufpe.br>.

*** Professor da Universidade Federal de Pernambuco (UFPE). Doutor em Psicologia. E-mail: <agmorais59@gmail.com.br>.
} 
O ensino da escrita alfabética nos critérios de avaliação do PNLD (1998-2016): Que conhecimentos...

the alphabetical writing system contemplated in these criteria in the Textbook Guidelines. The results showed: the first two editions of the Program contained few criteria related to this teaching axis, while the following editions progressively presented a growth in the number and diversity of knowledges/abilities which were evaluated. It was concluded that, initially, there seemed to be a certain contribution from the Program to the "literacy disinvention" in Brazil, but since 2010, there has been a gradual quest for conciliation between the teaching of the alphabetic writing system and reading practices and production of texts of different written genres, in the perspective of literacy with texts.

Keywords: Teaching of alphabetic writing. Literacy textbooks. Evaluation of textbooks. PNLD.

Resumen: Este artículo presenta resultados de una investigación que buscó analizar los criterios de evaluación de libros o colecciones de alfabetización, instituidos en el período de 1998 a 2016, en el Programa Nacional del Libro Didáctico $(P N L D)$. El enfoque fue en los conocimientos y las habilidades relativos al sistema de escritura alfabética contemplados en esos criterios en las Guías de Libros Didáticos. Los resultados evidenciaron: las dos primeras ediciones del Programa contenían pocos criterios relativos a ese eje de enseñanza, mientras que las siguientes presentaron, progresivamente, una ampliación en el número y en la variedad de criterios y de conocimientos/habilidades evaluados. Se concluyó, inicialmente, que, pareció haber cierta contribución del Programa para la "desinvención de la alfabetización" en Brasil, pero se observó, a partir de 2010, una búsqueda gradual de mayor conciliación entre la enseñanza del sistema de escritura y las prácticas de lectura y producción de textos de diferentes géneros escritos, en la perspectiva de alfabetizar enseñando a leer y escribir.

Palabras claves: Enseñanza de la escritura alfabética. Libros de alfabetización. Evaluación de libros didácticos. PNLD.

\section{Introdução}

O livro didático, que pode ser conceituado, a princípio, como “[...] aquele livro ou impresso empregado pela escola, para desenvolvimento de um processo de ensino ou de formação" (BATISTA, 2009, p. 41), inscreve-se na tradição da cultura escolar e constitui, certamente, um dos recursos pedagógicos mais usados cotidianamente por professores e estudantes de diferentes níveis de ensino de escolas de diversas partes do mundo. Na França, por exemplo, assim como no Brasil, a maioria dos professores usa um livro didático (CHARTIER, 2007), embora recorram a outros livros e a vários outros suportes textuais. É o que evidenciam os dados da ampla pesquisa Lire et Écrire, coordenada pelo Institut Français de l'Éducation e realizada em 131 classes de alfabetização (GOIGOUX, 2016), na qual se evidenciou que a maior parte dos professores franceses participantes do estudo $(70 \%)$ utilizava um livro didático.

No caso do Brasil, as antigas cartilhas de alfabetização tiveram - e, às vezes, ainda têm significativa presença nas salas de aula. Ao longo dos anos, sobretudo a partir da instituição do Programa Nacional do Livro Didático (PNLD), tais materiais foram progressivamente dando lugar, no mercado editorial, aos chamados "livros didáticos de alfabetização", que, atualmente, ainda convivem com as velhas cartilhas. Essa realidade deu origem a um número significativo de investigações sobre esses "novos livros" (FERREIRA et al., 2009; MONTEIRO, 2004; MORAIS, 2015; MORAIS; ALBUQUERQUE, 2005) e os seus processos de escolha e uso pelos professores (COSTA VAL et al., 2004; SILVA, 2005).

De modo geral, os resultados de tais estudos indicaram, por um lado, diferenças significativas entre as antigas cartilhas e os "novos livros didáticos"; e, por outro, a pouca adesão dos professores a esses últimos, pois eles "não alfabetizavam", ou melhor, tendiam a não contemplar um ensino explícito e sistemático de capacidades próprias da alfabetização, mais especificamente aquelas ligadas ao domínio do sistema de escrita alfabética (MORAIS; ALBUQUERQUE, 2005). Por esse motivo, os alfabetizadores recorriam a outros livros e materiais para alfabetizarem as crianças, entre os quais se incluíam as antigas cartilhas.

Práxis Educativa, Ponta Grossa, v. 16, e2117770, p. 1-22, 2021

Disponível em: <https://www.revistas2.uepg.br/index.php/praxiseducativa> 
Quando estabeleceu critérios de avaliação de livros didáticos de alfabetização, o PNLD instituiu e legitimou um conjunto de princípios e de abordagens teórico-metodológicas a serem considerados na produção de novos livros didáticos destinados às crianças da antiga $1^{\text {a }}$ série e, posteriormente, do ciclo de alfabetização, ao mesmo tempo que impulsionou mudanças em obras que já se encontravam em uso - às vezes, por um tempo considerável - nas salas de aula das escolas brasileiras.

Com relação a esse segundo aspecto, que não será tomado como objeto de análise neste artigo, esclarecemos que não vislumbramos uma relação direta e unilateral entre os critérios de avaliação instituídos no âmbito do PNLD e as mudanças nos livros didáticos, tendo em vista que tais mudanças não se relacionam exclusivamente a essa política pública. No entanto, parece-nos inegável o papel decisivo que essa política teve nas mudanças dos livros didáticos brasileiros e na melhoria da qualidade deles.

Quanto ao primeiro aspecto, que nos interessa mais diretamente neste trabalho, consideramos que os critérios de avaliação dos livros didáticos de alfabetização instaurados pelo PNLD representam sempre o resultado de um consenso provisório, negociado e revisto ao longo do tempo entre aqueles que dele participam e/ou têm o poder de decisão (especialistas, Ministério da Educação etc.).

O artigo que ora apresentamos inscreve-se nesse cenário e visa a analisar os critérios de avaliação dos livros ou coleções de alfabetização instituídos no âmbito do PNLD, no período de 1998 a 2016, com foco nos conhecimentos e nas habilidades relativos ao sistema de escrita alfabética contemplados nesses critérios. Desse modo, pretendemos contribuir para o campo de estudos em torno da avaliação de livros didáticos de alfabetização no Brasil, mediante a análise dos critérios de avaliação instituídos no âmbito de uma política pública do Governo brasileiro, durante quase duas décadas.

Tendo em vista esse objetivo, apresentaremos, na próxima seção, algumas reflexões sobre livros didáticos de alfabetização, antes e depois do advento do PNLD. Em seguida, situaremos a proposta metodológica da investigação realizada, circunscrevendo as fontes e os caminhos trilhados. Finalmente, serão apresentados os resultados do estudo, assim como as conclusões a que chegamos a partir deles.

\section{Livros didáticos de alfabetização: das antigas cartilhas ao PNLD}

No contexto brasileiro, sobretudo a partir da segunda metade do século XIX, os livros escolares de leitura comumente chamados de "cartilhas", que se inscreveram no próprio processo de institucionalização da escola (BATISTA; GALVÃO; KLINKE, 2002; FRADE, 2013), constituíram, ao longo do tempo, um suporte pedagógico tradicionalmente usado para ensinar e aprender a ler. Tais livros materializavam, por meio dos conteúdos, das atividades e da progressão propostos, o conjunto de princípios (psicológicos, linguísticos e pedagógicos) que sustentavam os métodos tradicionais de alfabetização, fossem eles sintéticos ou analíticos.

Conforme esclarece Frade (2013), tais manuais, inicialmente inspirados em modelos vindos da Europa (Portugal e França) e, depois, a partir dos anos de 1900, dos Estados Unidos, tiveram como antecessores diversos suportes manuscritos ou impressos para ensinar e/ou aprender a ler, como catecismos, abecedários, cartas do $\mathrm{ABC}$, silabários e tabelas/tábuas. Entretanto, como adverte a autora, não se trata de uma evolução linear, mas de um processo no qual esses suportes aparecem, desaparecem e mudam de acordo com as práticas e a organização da classe.

Práxis Educativa, Ponta Grossa, v. 16, e2117770, p. 1-22, 2021

Disponível em: <https://www.revistas2.uepg.br/index.php/praxiseducativa> 
Nos anos de 1980, as cartilhas de alfabetização, assim como os métodos tradicionais de ensino de leitura e de escrita a elas vinculados, tornaram-se objeto de críticas contundentes, e o seu uso passou a ser sistematicamente condenado. Tais críticas e condenações foram impulsionadas, sobretudo, pelos altos índices de fracasso escolar àquela época e, também, por mudanças conceituais no campo da alfabetização, provocadas, especialmente, pela teoria construtivista da psicogênese da escrita (FERREIRO; TEBEROSKY, 1985), que deslocou a discussão sobre o "como se ensina" para o "como se aprende".

Morais e Albuquerque (2005), por meio da análise de duas cartilhas muito usadas até os anos de 1990 e de dois livros de alfabetização recomendados pelo PNLD 2004, constataram que as primeiras, além de apresentarem os chamados textos cartilhados, não incluíam atividades de produção textual. Além disso, observaram que as atividades contidas nessas cartilhas consistiam, principalmente, na leitura de sílabas, de palavras, de frases e de pseudotextos; cópia de sílabas, de palavras e de frases; escrita de palavras e exploração de diferentes tipos de letra.

As atividades presentes naquelas cartilhas, que levavam a criança a sempre receber, copiar e repetir informações "prontas" sobre relações grafema-fonema, expressavam uma visão empiristaassociacionista de aprendizagem e seu implícito viés adultocêntrico. Desse modo, diferentemente do propugnado por Ferreiro e Teberosky (1985), os autores de cartilhas (não importa se pautados por métodos sintéticos ou analíticos) concebiam que a criança já compreenderia as letras da mesma forma que um indivíduo plenamente alfabetizado e, assim, para vir a ler e a escrever palavras, precisaria apenas repetir e memorizar quais letras correspondiam a quais sons em sua língua.

Na década de 1990, surgiram, no Brasil, os chamados "livros de alfabetização", os quais se relacionam, por um lado, à difusão de novas perspectivas teóricas no campo da alfabetização; e, por outro, ao impacto da avaliação pedagógica desenvolvida pelo PNLD. Criado em 1985 pelo Ministério da Educação (MEC), por meio do Decreto-Lei No 91.542, de 19 de agosto (BRASIL, 1985), esse Programa teve, segundo Batista e Costa Val (2004), suas características alteradas a partir de 1996, quando se iniciou o processo de avaliação pedagógica dos livros didáticos. Desde então, os objetivos centrais do PNLD têm sido a avaliação, a aquisição e a distribuição de livros didáticos para os alunos das escolas públicas.

Como decorrência desse processo, assistimos, ao longo do tempo, a uma mudança significativa dos livros didáticos submetidos ao PNLD. De acordo com Costa Val e Castanheira (2005), entre 1998 e 2004, houve uma diminuição do número de obras não aceitas e um aumento gradativo de obras aprovadas, nas áreas de alfabetização e de língua portuguesa. Essas autoras constataram, também, naquele mesmo período, um crescimento do volume de livros com menções mais altas ("recomendadas com distinção" e "recomendadas"), embora, em todas as avaliações até então realizadas, essas menções tenham sido menos frequentes que a mais baixa (recomendada com ressalvas) ${ }^{1}$.

Monteiro (2004), ao analisar a tendência da produção editorial dos livros didáticos de alfabetização inscritos no PNLD de 1998 e no de 2001, observou, de uma avaliação para a outra, uma diminuição significativa no número de livros vinculados aos métodos tradicionais e, em um movimento contrário, um aumento de obras que se identificavam com os pressupostos da psicogênese da escrita e das teorias da enunciação. Contudo, alguns estudos, como o de Morais e

\footnotetext{
1 As categorias "recomendada com distinção", "recomendada" e "recomendada com ressalvavas" eram utilizadas, na época, pelo PNLD, para classificar os livros aprovados. A partir de 2007, tais menções foram abandonadas pelo Programa.
}

Práxis Educativa, Ponta Grossa, v. 16, e2117770, p. 1-22, 2021 
Albuquerque (2005), já citado anteriormente, constataram, nesses novos livros didáticos, a presença do fenômeno da "desinvenção da alfabetização" (SOARES, 2004).

Morais e Albuquerque (2005) perceberam que os novos livros didáticos analisados tendiam a apresentar uma diversidade de textos de diferentes gêneros, o que evidenciava uma preocupação com o letramento. No entanto, o ensino da escrita alfabética ocupava, nessas obras, um lugar secundário, tanto em relação ao número de atividades, quanto à natureza delas. De modo geral, as poucas atividades propostas envolviam palavras ou letras como unidades de análise e quase não exploravam a reflexão fonológica. Havia também uma opção por não realizar atividades envolvendo sílabas, provavelmente como uma forma de diferenciar-se das cartilhas tradicionais, e tampouco se encontrava, nos novos livros de alfabetização, uma clara progressão e explicitude no ensino das correspondências entre grafemas e fonemas.

Costa Val e Castanheira (2005), ao delinearem o perfil das obras de alfabetização e de língua portuguesa ( $1^{\mathrm{a}}$ a $4^{\mathrm{a}}$ série) avaliadas no PNLD 2004, constataram resultados semelhantes, na medida em que observaram muitas obras que não enfocavam, de forma significativa, aspectos que diziam respeito ao processo de apropriação da escrita alfabética, como a já mencionada exploração das relações entre fonemas e grafemas. Segundo as autoras, a ausência de trabalho sistemático nessa direção contribuiria para as inúmeras dificuldades da escola pública brasileira em garantir a alfabetização das crianças.

Ferreira et al. (2009), ao analisarem mudanças ocorridas em cinco livros de alfabetização, por meio da comparação de suas versões aprovadas no PNLD 2004 e no PNLD 2007, perceberam que, na última edição, os livros examinados tentavam equilibrar as atividades voltadas ao letramento com as que promoviam o sistema de escrita. Em contrapartida, constataram que, nos livros analisados, as atividades voltadas ao eixo da escrita alfabética não eram em número suficiente, embora apresentassem diversidade, excetuando-se um dos livros, que privilegiava atividades de cópia e de memorização.

Quando consideramos o conjunto de livros de alfabetização aprovados no PNLD 2007, observamos, porém, que predominavam, segundo informações do Guia de Livros Didáticos (BRASIL, 2006), obras que não abordavam de forma equilibrada os diferentes componentes da alfabetização e do letramento, pois, dos 47 livros aprovados, 21 tratariam de forma desigual essas duas dimensões e 10 privilegiariam a abordagem da apropriação do sistema de escrita, o que equivale a cerca de $65 \%$ das obras. Já os livros que se julgou abordarem de forma equilibrada essas dimensões correspondiam, aproximadamente, a 34\% das obras (16 livros).

Silva (2009), ao analisar as resenhas das obras aprovadas no PNLD 2007 pertencentes ao primeiro e ao terceiro blocos - livros que abordavam de forma desigual a alfabetização e o letramento, e livros que privilegiavam a apropriação do sistema de escrita -, observou que essas obras tendiam a priorizar a aprendizagem do sistema de escrita e tinham em comum algumas características dos métodos analíticos ou analítico-sintéticos de alfabetização. Esse dado revela, assim, um panorama distinto do observado no PNLD 2004, o que pode estar associado a um possível "efeito adverso" dessa política pública na configuração das obras aprovadas. É provável que, ante a "desinvenção da alfabetização" constatada nos livros didáticos, o PNLD tenha impulsionado, por meio dos resultados da avaliação da edição anterior, uma retomada da priorização do ensino do sistema de escrita, ainda que não exatamente como esperado.

Na edição mais recente do PNLD aqui considerada, a de 2016, foram avaliadas, conforme o Guia de Livros Didáticos (BRASIL, 2015), 35 coleções de letramento e alfabetização, das quais $21(60 \%)$ foram aprovadas. De modo geral, de acordo com esse documento, observou-se, nos volumes do $1^{\circ}$ ano do Ensino Fundamental, um aumento da presença de textos da tradição oral

Práxis Educativa, Ponta Grossa, v. 16, e2117770, p. 1-22, 2021 Disponível em: <https://www.revistas2.uepg.br/index.php/praxiseducativa> 
O ensino da escrita alfabética nos critérios de avaliação do PNLD (1998-2016): Que conhecimentos...

(cantigas, adivinhas, trava-línguas e parlendas) e de atividades que contribuem para a compreensão do sistema de escrita alfabética. Sobretudo nos volumes do $2^{\circ}$ e $3^{\circ}$ anos do Ensino Fundamental, percebeu-se sistematização do ensino das correspondências som-grafia. Consideramos, portanto, que a exploração sistemática e reflexiva da notação alfabética, associada a uma coletânea textual diversificada e a atividades significativas de leitura e de produção de diferentes gêneros de textos, contribui para a consolidação da perspectiva de alfabetizar letrando nos livros didáticos, o que, para nós, revela um evidente cenário de significativa ampliação da qualidade do conjunto de obras que vinham sendo disponibilizados às crianças e aos alfabetizadores do país.

\section{Metodologia do estudo}

Adotamos, neste estudo, a análise documental como procedimento metodológico que envolve descrição ou transcrição, ordenação e seleção das informações contidas nos documentos (LAVILLE; DIONNE, 1999), partindo da concepção de documento elaborada por Le Goff (1996): produto de uma montagem, consciente ou não, da sociedade que os produziu, segundo as relações de forças instituídas em uma determinada época e contexto histórico.

Os dados gerados pela análise documental foram tratados com o apoio da análise de conteúdo, que contempla processos de descrição, de inferência e de interpretação (BARDIN, 2004). A análise foi desenvolvida por meio de recorte do conteúdo por temas (análise temática categorial) e envolveu, adotando uma abordagem qualitativa e quantitativa, as etapas indicadas pela autora supracitada: pré-análise, análise do material e tratamento dos resultados, inferência e interpretação.

As análises documental e de conteúdo desenvolvidas tiveram como fonte diferentes edições do Guia de Livros Didáticos do PNLD - documento que apresenta os critérios adotados no processo de avaliação das obras e as resenhas dos livros ou das coleções aprovadas - que contemplaram a avaliação de livros ou coleções de alfabetização (1998, 2004, 2007, 2010, 2013 e 2016) ${ }^{2}$. Nesses documentos, analisamos, sobretudo, as fichas de avaliação dos/das livros/coleções, tomando como objeto de análise os critérios avaliativos referentes ao eixo do sistema de escrita alfabética.

Trata-se de um estudo de corte longitudinal, no qual um conjunto de critérios, que foram agrupados em categorias, foi analisado ao longo dos anos. Ademais, ressaltamos que esse recorte temporal compreende dois conjuntos de dados distintos que serão tratados de modo integrado: aqueles relativos à avaliação de "livros de alfabetização" (PNLD 1998, 2000/2001, 2004, 2007), que correspondem ao livro da antiga $1^{a}$ série ou do $1^{\mathrm{o}}$ ano do Ensino Fundamental, e os que se referem à avaliação de "coleções de alfabetização", constituídas por dois (PNLD 2010) ou por três livros (PNLD 2013 e 2016), correspondentes aos dois ou aos três primeiros anos daquele segmento escolar. Salientamos que, nas análises realizadas, tais especificidades foram levadas em conta.

No tratamento e na categorização dos dados obtidos, no qual consideramos não apenas as informações explícitas contidas nos documentos, mas também as implícitas, adotamos o modelo aberto da análise de conteúdo (LAVILLE; DIONNE, 1999), de acordo com o qual as categorias são construídas e reconstruídas ao longo do processo de análise dos dados. Nesses termos, os critérios estabelecidos em cada edição do PNLD foram agrupados em função de suas semelhanças ou proximidades temáticas, reunindo, em uma mesma categoria, critérios que se relacionavam a um mesmo conhecimento ou habilidade relativos à notação alfabética. Após essa categorização,

\footnotetext{
2 A pesquisa à qual este artigo está vinculado é anterior ao PNLD 2019. Por esse motivo, essa edição do Programa não será contemplada. Além disso, os processos de avaliação e de seleção dos livros didáticos foram significativamente alterados a partir de 2017, implicando algumas rupturas e, a nosso ver, até mesmo retrocessos na dinâmica do PNLD.
}

Práxis Educativa, Ponta Grossa, v. 16, e2117770, p. 1-22, 2021

Disponível em: < https://www.revistas2.uepg.br/index.php/praxiseducativa> 
que foi realizada por dois pesquisadores independentes - e, em caso de desacordo, por um terceiro ${ }^{3}$ -, analisamos a presença ou a ausência dessas categorias de critérios, ao longo dos anos, assim como a sua frequência, a fim de identificar mudanças e permanências neles.

\section{Resultados e discussões}

Os critérios de avaliação dos livros ou coleções de alfabetização relativos ao sistema de escrita alfabética, instituídos no âmbito do PNLD, no período de 1998 a 2016, aparecem, ao longo dos anos, em seções da ficha de avaliação ${ }^{4}$ que apresentam diferentes denominações. No Guia de 2000/2001, tais critérios estão reunidos nas seções "Processo de alfabetização" e "Aquisição do sistema ortográfico". Já no Guia de 2004, tais critérios estão concentrados nas seções "Processo de alfabetização" e "Apropriação do sistema alfabético e das convenções da escrita". Em 2007, os critérios são elencados na seção "A tecnologia da escrita" e, na edição de 2010, aparecem no item "Aquisição do sistema alfabético". Já em 2013 e 2016, constam em "Conhecimentos linguísticos", que contemplam tanto a aprendizagem do sistema alfabético de escrita e o domínio das convenções som-grafia, quanto outros conhecimentos linguísticos ${ }^{6}$.

Essa última configuração demonstra o reconhecimento de que a apropriação da notação alfabética e o domínio das correspondências som-grafia estão incluídos no amplo eixo didático designado de "análise linguística", "análise e reflexão sobre língua" ou "conhecimentos linguísticos". Essa opção revela uma sintonia com a organização dos direitos de aprendizagem do Pacto Nacional para Alfabetização na Idade Certa (PNAIC), instituído em 2013, no qual o eixo da "análise linguística" é explicitamente constituído pela "apropriação do sistema de escrita alfabética" e pelos subeixos "discursividade", "textualidade" e "normatividade".

Por meio de uma análise preliminar, agrupamos os critérios contidos nessas seções em três grandes grupos principais. No primeiro grupo, que se relaciona aos conhecimentos dos aprendizes sobre a língua, encontramos apenas dois critérios, que aparecem, respectivamente, nas edições de 2000/2001 e 2004 do PNLD: "Adequação à competência linguística e comunicativa da criança" e "Consideração das hipóteses/processos de aprendizagem”. Esse último critério parece demonstrar, como também observaram Albuquerque e Ferreira (2019), uma influência da teoria da psicogênese da escrita (FERREIRO; TEBEROSKY, 1985).

No segundo grupo, incluem-se vários dos critérios gerais constantes no Guia de Livros Didáticos do PNLD 2000/2001, que não se relacionam especificamente ao eixo da apropriação do sistema de escrita: "Correção dos conceitos e das definições"; "Exercícios de sensibilização/observação"; "Exercícios de aplicação"; "Exercícios de memorização, quando pertinentes"; "Orientação para a construção de conceitos e regras"; "Clareza e correção na

\footnotetext{
3 A categorização inicial dos dados foi realizada, separadamente, por dois juízes (uma bolsista de iniciação científica e o seu orientador, o primeiro autor deste artigo). Nos poucos casos de desacordo, recorreu-se ao julgamento do outro pesquisador integrante da equipe (o segundo autor deste artigo).

4 A título de esclarecimento, informamos que o Guia de Livros Didáticos do PNLD 1998 não divulgava a ficha de avaliação. Na seção que explicita os "Critérios para análise" da área de língua portuguesa, que se subdividem em critérios relativos à natureza dos textos e critérios relativos ao trabalho com o texto (leitura, produção e conhecimentos linguísticos), não constam critérios específicos relativos ao sistema de escrita alfabética.

${ }^{5}$ Considerando que os conhecimentos ortográficos aparecem nos Guias do PNLD associados, geralmente, ao sistema de escrita alfabética, incluímo-los em nossa análise, apesar de distinguirmos, assim como Morais (1998), sistema de escrita alfabética e norma ortográfica.

${ }^{6}$ Em 2013 e 2016, foram avaliadas coleções constituídas por três livros, correspondentes aos três primeiros anos do Ensino Fundamental, o que explica a inclusão dos conhecimentos e habilidades relativos ao sistema de escrita em um eixo mais amplo, que contempla outros conhecimentos linguísticos, como ortografia, pontuação etc.
}

Práxis Educativa, Ponta Grossa, v. 16, e2117770, p. 1-22, 2021 Disponível em: < https://www.revistas2.uepg.br/index.php/praxiseducativa> 
O ensino da escrita alfabética nos critérios de avaliação do PNLD (1998-2016): Que conhecimentos...

formulação dos exercícios"; "Progressão no grau de complexidade dos exercícios"; "Variedade na formulação dos exercícios"”.

No Guia do PNLD 2004, também encontramos vários critérios semelhantes a esses: "Correção de conceitos e definições"; "Orientação para a construção de conceitos e regras"; "Contribuição para o desenvolvimento das habilidades de": "a) observação"; "b) análise (comparação e estabelecimento de relações entre informações)"; "c) generalização (estabelecimento de regras gerais de funcionamento de fenômeno linguístico; conclusões gerais estabelecidas após observação e análise)"; "d) memorização"; e "e) aplicação". A partir do PNLD 2007, critérios dessa natureza integram um tópico mais geral (por exemplo, "Proposta pedagógica") e, portanto, não mais aparecem vinculados à apropriação do sistema de escrita.

Já no terceiro grupo, que constitui objeto de estudo deste trabalho e engloba a grande maioria dos critérios, situamos aqueles que se referem aos conhecimentos e às habilidades relacionados à escrita alfabética. Considerando esses critérios, construímos categorias temáticas que contemplam esses diferentes conhecimentos e habilidades nos critérios de avaliação do PNLD, conforme pode ser observado no Quadro 1 a seguir.

Quadro 1 - Conhecimentos e habilidades relativos à escrita alfabética contemplados nos critérios de avaliação do PNLD (1998-2016)

\begin{tabular}{|c|c|c|c|c|c|c|c|c|}
\hline $\begin{array}{l}\text { Conhecimentos e } \\
\text { habilidades }\end{array}$ & $\begin{array}{c}\text { PNLD } \\
1998\end{array}$ & $\begin{array}{c}\text { PNLD } \\
2000 / \\
2001 \\
\end{array}$ & $\begin{array}{l}\text { PNLD } \\
2004\end{array}$ & $\begin{array}{c}\text { PNLD } \\
2007\end{array}$ & $\begin{array}{l}\text { PNLD } \\
2010\end{array}$ & $\begin{array}{l}\text { PNLD } \\
2013\end{array}$ & $\begin{array}{l}\text { PNLD } \\
2016\end{array}$ & $\begin{array}{c}\text { Total } \\
\text { de } \\
\text { edições }\end{array}$ \\
\hline $\begin{array}{l}\text { Compreensão das } \\
\text { relações entre a escrita e } \\
\text { as partes sonoras das } \\
\text { palavras. }\end{array}$ & & $\mathrm{X}$ & $\mathrm{X}$ & $\mathrm{X}$ & $\mathrm{X}$ & $\mathrm{X}$ & $\mathrm{X}$ & 6 \\
\hline $\begin{array}{l}\text { Exploração da } \\
\text { consciência fonológica. }\end{array}$ & & & & $\mathrm{X}$ & $\mathrm{X}$ & & & 2 \\
\hline $\begin{array}{l}\text { Diferenciação da escrita } \\
\text { (letras) de outros } \\
\text { sistemas de notação. }\end{array}$ & & & & $\mathrm{X}$ & $\mathrm{X}$ & $\mathrm{X}$ & $\mathrm{X}$ & 4 \\
\hline $\begin{array}{l}\text { Reconhecimento das } \\
\text { letras do alfabeto. }\end{array}$ & & & & $\mathrm{X}$ & $\mathrm{X}$ & $\mathrm{X}$ & $\mathrm{X}$ & 4 \\
\hline $\begin{array}{l}\text { Exploração de diferentes } \\
\text { tipos de letras. }\end{array}$ & & $\mathrm{X}$ & $\mathrm{X}$ & $\mathrm{X}$ & $\mathrm{X}$ & $\mathrm{X}$ & $\mathrm{X}$ & 6 \\
\hline Exploração da caligrafia. & & & & $\mathrm{X}$ & & & & 1 \\
\hline $\begin{array}{l}\text { Exploração de diferentes } \\
\text { estruturas silábicas. }\end{array}$ & & & & $\mathrm{X}$ & $\mathrm{X}$ & $\mathrm{X}$ & $\mathrm{X}$ & 4 \\
\hline $\begin{array}{l}\text { Comparação de palavras } \\
\text { quanto ao número de } \\
\text { letras e de sílabas. }\end{array}$ & & & & $\mathrm{X}$ & & & & 1 \\
\hline $\begin{array}{l}\text { Compreensão do } \\
\text { conceito de palavra. }\end{array}$ & & & & $\mathrm{X}$ & $\mathrm{X}$ & & & 2 \\
\hline $\begin{array}{l}\text { Exploração de palavras } \\
\text { estáveis ou formas fixas. }\end{array}$ & & & & $\mathrm{X}$ & & & & 1 \\
\hline $\begin{array}{l}\text { Conhecimento de outras } \\
\text { convenções da escrita } \\
\text { (direções da escrita, } \\
\text { segmentação/ } \\
\text { espaçamento entre } \\
\text { palavras. }\end{array}$ & & & $\mathrm{X}$ & $\mathrm{X}$ & & & $\mathrm{X}$ & 3 \\
\hline
\end{tabular}

\footnotetext{
7 No Guia do PNLD 2000/2001, assim como no de 2004, aparecem, também, respectivamente, os critérios "Consideração da variação dialetal" e "Exploração das variedades dialetais", que, apesar de constarem nas seções da ficha de avaliação relativas à apropriação do sistema alfabético, parecem-nos estar vinculados ao eixo da linguagem oral.
}

Práxis Educativa, Ponta Grossa, v. 16, e2117770, p. 1-22, 2021 Disponível em: <https://www.revistas2.uepg.br/index.php/praxiseducativa> 


\begin{tabular}{|l|c|c|c|c|c|c|c|c|}
\hline \multicolumn{1}{|c|}{$\begin{array}{c}\text { Conhecimentos e } \\
\text { habilidades }\end{array}$} & $\begin{array}{c}\text { PNLD } \\
\mathbf{1 9 9 8}\end{array}$ & $\begin{array}{c}\text { PNLD } \\
\mathbf{2 0 0 0 /} \\
\mathbf{2 0 0 1}\end{array}$ & $\begin{array}{c}\text { PNLD } \\
\mathbf{2 0 0 4}\end{array}$ & $\begin{array}{c}\text { PNLD } \\
\mathbf{2 0 0 7}\end{array}$ & $\begin{array}{c}\text { PNLD } \\
\mathbf{2 0 1 0}\end{array}$ & $\begin{array}{c}\text { PNLD } \\
\mathbf{2 0 1 3}\end{array}$ & $\begin{array}{c}\text { PNLD } \\
\mathbf{2 0 1 6}\end{array}$ & $\begin{array}{c}\text { Total } \\
\text { de } \\
\text { edições }\end{array}$ \\
\hline $\begin{array}{l}\text { Conhecimento de regras } \\
\text { e irregularidades } \\
\text { ortográficas. }\end{array}$ & & $\mathrm{X}$ & & & $\mathrm{X}$ & $\mathrm{X}$ & $\mathrm{X}$ & 3 \\
\hline Leitura de palavras. & & & & & $\mathrm{X}$ & $\mathrm{X}$ & $\mathrm{X}$ & 3 \\
\hline Leitura de frases. & & & & & $\mathrm{X}$ & $\mathrm{X}$ & $\mathrm{X}$ & 3 \\
\hline Leitura de textos curtos. & & & & & $\mathrm{X}$ & $\mathrm{X}$ & $\mathrm{X}$ & 3 \\
\hline Escrita de palavras. & & & & & $\mathrm{X}$ & $\mathrm{X}$ & $\mathrm{X}$ & 3 \\
\hline Escrita de frases. & & & & $\mathrm{X}$ & & & & 1 \\
\hline $\begin{array}{l}\text { Uso adequado de } \\
\text { suportes de leitura e } \\
\text { escrita. }\end{array}$ & & & & & & & & \\
\hline \multicolumn{1}{|c|}{ Total } & 0 & 2 & 4 & 12 & 12 & 11 & 12 & \\
\hline
\end{tabular}

Fonte: Elaborado pelos autores. Dados da pesquisa a partir de Brasil (1998, 2000, 2003, 2006, 2009, 2012, 2015).

Os dados apresentados no Quadro 1 evidenciam, de modo geral, a existência de uma diversidade de conhecimentos e de habilidades relativos à escrita alfabética, que, a cada edição do PNLD, foram sendo progressivamente ampliados. Como podemos também ver, em um exame inicial do Quadro 1, as categorias que agrupam critérios assumidos pelo PNLD ao longo dos anos tinham naturezas diversas, contemplando diferentes dimensões da aprendizagem da escrita alfabética, como a compreensão das relações entre a notação escrita e os segmentos sonoros das palavras, a consciência fonológica e o conhecimento de letras e de diferentes estruturas silábicas, além da leitura e da escrita de palavras. Entretanto, encontramos conhecimentos e habilidades que não envolvem estritamente a apropriação do sistema de escrita, como é o caso do conhecimento de regras e de irregularidades ortográficas e da leitura de textos curtos e da escrita de frases.

Nas edições iniciais (2000/2001 e 2004), são contemplados, respectivamente, apenas duas e quatro categorias de conhecimentos/habilidades. Relembremos que, no Guia de 1998, não havia explicitação de critérios relativos a esse eixo de ensino, embora as exigências em torno da seleção textual e da leitura/compreensão e produção de textos já estivessem bem mais definidas, o que parece revelar um cuidado maior com a dimensão do letramento do que com a que se refere à apropriação da escrita alfabética. A partir da edição de 2007, percebemos uma ampliação progressiva e significativa das categorias relativas ao sistema de escrita alfabética abordadas, que contemplam, a cada edição, 11 ou 12 conhecimentos/habilidades tratados/as como vinculados/as ao domínio do sistema de escrita.

Considerando ainda os dados do Quadro 1, observamos, por um lado, que os conhecimentos/habilidades mais recorrentes nos critérios de avaliação do PNLD, ao longo dos anos, referem-se, sobretudo, à compreensão das relações entre a escrita e as partes sonoras das palavras (6/6), à exploração de diferentes tipos de letras (6/6), ao reconhecimento das letras do alfabeto (4/6) e à diferenciação da escrita (letras) de outros sistemas de notação (4/6), além do conhecimento de regras e de irregularidades ortográficas (4/6). Por outro lado, os conhecimentos/habilidades menos contemplados foram a exploração da caligrafia $(1 / 6)$ e de palavras estáveis ou formas fixas (1/6), além da comparação de palavras quanto ao número de letras e de sílabas $(1 / 7)$ e do uso adequado de suportes de leitura e escrita $(1 / 6)^{8}$.

Para aprofundarmos as análises efetuadas, optamos por agrupar os/as diferentes conhecimentos/habilidades contemplados/as nas diferentes edições do PNLD em seis grandes categorias ou blocos: 1) Compreensão das relações entre a escrita e as partes sonoras das palavras

${ }^{8}$ Para efeito de quantificação, não consideramos a edição de 1998, já que ela não disponibilizava a ficha de avaliação.

Práxis Educativa, Ponta Grossa, v. 16, e2117770, p. 1-22, 2021

Disponível em: <https://www.revistas2.uepg.br/index.php/praxiseducativa> 
O ensino da escrita alfabética nos critérios de avaliação do PNLD (1998-2016): Que conhecimentos...

e exploração da consciência fonológica; 2) Conhecimento das letras do alfabeto; 3) Conhecimento de estruturas silábicas; 4) Compreensão do conceito de palavra e conhecimento de palavras estáveis ou formas fixas; 5) Conhecimento de regras e irregularidades ortográficas e de outras convenções da escrita; e 6) Leitura e escrita de palavras, frases e textos curtos.

\section{Compreensão das relações entre a escrita e as partes sonoras das palavras e exploração da consciência fonológica}

$\mathrm{O} / \mathrm{A}$ conhecimento/habilidade relativo à "compreensão das relações entre a escrita e as partes sonoras das palavras" foi, como vimos, um dos mais frequentes, ao longo dos anos, constando em todas as edições do PNLD, à exceção da de 1998, no qual aparece uma menção às relações entre "sistema fonológico" e "sistema ortográfico" nos "Princípios gerais" explicitados na "Introdução" da seção do Guia de Livros Didáticos destinada à área de Língua Portuguesa (BRASIL, 1998).

Nas edições seguintes do PNLD, conforme podemos observar no Quadro 2, esse/a conhecimento/habilidade reúne diferentes critérios que têm em comum a abordagem das relações entre a escrita e as unidades sonoras das palavras.

Quadro 2 - Critérios de avaliação do PNLD (2000/2001-2016) referentes à compreensão das relações entre a escrita e as partes sonoras das palavras

\begin{tabular}{|c|c|c|c|c|c|}
\hline $\begin{array}{c}\text { PNLD } \\
2000 / 2001\end{array}$ & PNLD 2004 & PNLD 2007 & PNLD 2010 & PNLD 2013 & PNLD 2016 \\
\hline $\begin{array}{l}\text { Consideração } \\
\text { das relações } \\
\text { oral-escrita. } \\
\text { Exercícios } \\
\text { adequados de } \\
\text { relação letra- } \\
\text { som. }\end{array}$ & $\begin{array}{l}\text { Exploração das } \\
\text { relações } \\
\text { oralidade/escrita. } \\
\text { Exploração das } \\
\text { relações } \\
\text { fonema/grafema. }\end{array}$ & $\begin{array}{l}\text { Compreender } \\
\text { a existência de } \\
\text { relação entre } \\
\text { escrita e pauta } \\
\text { sonora. } \\
\text { Estabelecer } \\
\text { relações entre } \\
\text { grafemas e } \\
\text { fonemas. }\end{array}$ & $\begin{array}{l}\text { Analisar as } \\
\text { relações entre as } \\
\text { unidades sonoras } \\
\text { de palavras, } \\
\text { (sílabas, } \\
\text { fonemas) e suas } \\
\text { correspondentes } \\
\text { na escrita. }\end{array}$ & $\begin{array}{l}\text { Compreensão das } \\
\text { relações entre o } \\
\text { sistema fonológico } \\
\text { e o sistema de } \\
\text { escrita do } \\
\text { Português (por } \\
\text { exemplo, por meio } \\
\text { de atividades de } \\
\text { comparação de } \\
\text { palavras orais com } \\
\text { suas escritas } \\
\text { correspondentes; } \\
\text { análise oral de } \\
\text { sílabas escritas; } \\
\text { síntese escrita de } \\
\text { sílabas orais; } \\
\text { análise de letras } \\
\text { iniciais e finais de } \\
\text { palavras e de suas } \\
\text { semelhanças } \\
\text { sonoras; produção } \\
\text { e identificação de } \\
\text { rimas e } \\
\text { aliterações). }\end{array}$ & $\begin{array}{l}\text { [As atividades] } \\
\text { organizam-se de } \\
\text { forma a propiciar a } \\
\text { compreensão das } \\
\text { relações que se } \\
\text { estabelecem entre } \\
\text { o sistema } \\
\text { fonológico e o } \\
\text { sistema de escrita } \\
\text { do Português (por } \\
\text { exemplo, por meio } \\
\text { de atividades de } \\
\text { comparação de } \\
\text { palavras orais com } \\
\text { suas escritas } \\
\text { correspondentes; } \\
\text { análise oral de } \\
\text { sílabas escritas; } \\
\text { síntese escrita de } \\
\text { sílabas orais; } \\
\text { análise de letras } \\
\text { iniciais e finais de } \\
\text { palavras e de suas } \\
\text { semelhanças } \\
\text { sonoras; produção } \\
\text { e identificação de } \\
\text { rimas e } \\
\text { aliterações)? }\end{array}$ \\
\hline
\end{tabular}

Fonte: Elaborado pelos autores. Dados da pesquisa com base em Brasil (2000, 2003, 2006, 2009, 2012, 2015).

Nesse mesmo Quadro 2, percebemos que, até o PNLD 2007, os critérios contemplavam tais relações tanto de modo mais amplo ("relações oral-escrita", "relações oralidade/escrita" e "relação entre escrita e pauta sonora") quanto de modo mais estrito ("relação letra-som", "relações 
fonema-grafema" e "relações entre grafemas e fonemas"). A partir do PNLD 2010, são incluídas relações entre outras unidades sonoras e escritas além daquelas que envolvem letras ou grafemas e fonemas, que são mais complexas e constituem o ponto de chegada do processo de compreensão do princípio alfabético. Nesse sentido, no PNLD 2010, aparecem "sílabas" e "fonemas", enquanto nos PNLD 2013 e 2016 observamos "palavras", "sílabas", "letras iniciais e finais de palavras e suas semelhanças sonoras", além de "rimas e aliterações".

Ressaltamos, por um lado, as oscilações e as imprecisões entre as terminologias adotadas e os problemas conceituais a elas subjacentes - "sistema ortográfico" em vez de "sistema alfabético"; "sistema ortográfico" em lugar de "norma ortográfica"; "sistema de escrita" como provável equivalente de "relação letra-som" ou "relações entre grafemas e fonemas". Por outro lado, cabe sublinharmos a ausência de clara diferenciação, nas primeiras edições do Programa, entre a compreensão do sistema alfabético e o domínio dessas correspondências entre grafemas e fonemas, que necessariamente implica alguma memorização e não só a compreensão de propriedades conceituais. Apenas no PNLD 2016, aparece explicitamente, no título da seção destinada à avaliação dos/das conhecimentos/habilidades relacionados à notação alfabética, a menção "As atividades: apropriação do sistema de escrita alfabética e domínio de suas convenções som-grafia", acompanhada do critério global "As atividades realizam um trabalho sistemático que promova a compreensão do sistema alfabético e o domínio de suas convenções som-grafia?”.

Apesar de tais oscilações, entendemos que a presença de critérios ligados à compreensão das relações entre a escrita e as partes sonoras das palavras, em praticamente todas as edições do PNLD, explica-se pela sua inarredável relevância no processo de alfabetização, tendo em vista que, para apropriar-se do sistema alfabético, é necessário compreender que as letras substituem os sons da fala e que letras ou grupos de letras notam unidades sonoras menores que as sílabas (os fonemas), vindo a memorizar essas relações entre unidades orais mínimas e grafemas. Como observa Soares (2016, p. 46, grifos da autora), "[...] aprender a escrita alfabética é, fundamentalmente, um processo de converter sons da fala em letras ou combinação de letras escrita -, ou converter letras, ou combinação de letras, em sons da fala - leitura".

Leal et al. (2013), ao analisarem orientações sobre o ensino do sistema de escrita alfabética em 26 documentos curriculares brasileiros (12 de Secretarias Municipais de Educação de capitais e 14 de Secretarias Estaduais de Educação), elaborados ou reformulados na primeira década do século XXI, também observaram orientações variadas relativas às reflexões sobre a dimensão sonora das palavras e suas relações com a escrita. Conforme os dados do estudo, em mais da metade dos documentos analisados (53,8\%), foram contemplados/as os/as conhecimentos/habilidades "compreender que a escrita nota propriedades da pauta sonora" e "compreender que as letras correspondem aos fonemas". No contexto brasileiro, interpretamos que tal preocupação com a compreensão do funcionamento da escrita alfabética refletiria a disseminação da teoria da psicogênese da escrita, que foi explicitamente assumida como marco explicativo pelos Parâmetros Curriculares Nacionais de $1^{\mathrm{a}}$ a $4^{\mathrm{a}}$ séries do Ensino Fundamental alguns anos antes (BRASIL, 1997).

A "exploração da consciência fonológica", que se refere às variadas habilidades de reflexão consciente sobre os segmentos sonoros das palavras, como sílabas, rimas, aliterações e fonemas (MORAIS, 2012, 2019b; SOARES, 2016), é uma dimensão intimamente relacionada à anterior, tendo em vista que tais habilidades são necessárias à compreensão das relações entre partes sonoras e partes escritas das palavras. No Quadro 3, a seguir, indicamos os critérios relativos a esse/a conhecimento/habilidade.

Práxis Educativa, Ponta Grossa, v. 16, e2117770, p. 1-22, 2021

Disponível em: < https://www.revistas2.uepg.br/index.php/praxiseducativa $>$ 
O ensino da escrita alfabética nos critérios de avaliação do PNLD (1998-2016): Que conhecimentos...

Quadro 3 - Critérios de avaliação do PNLD (2000/2001-2016) referentes à exploração da consciência fonológica

\begin{tabular}{|l|l|}
\hline \multicolumn{1}{|c|}{ PNLD 2007 } & \multicolumn{1}{c|}{ PNLD 2010 } \\
\hline Desenvolver a consciência fonológica. & Identificar o fonema como unidade sonora. \\
Identificar a sílaba como unidade fonológica. & Identificar a sílaba como unidade sonora. \\
\hline
\end{tabular}

Fonte: Elaborado pelos autores. Dados da pesquisa com base em Brasil (2006, 2009).

Como podemos observar no Quadro 3, apenas nas edições de 2007 e 2010 do PNLD essa dimensão apareceu de modo independente entre os critérios de avaliação. Consideramos que a ausência desses critérios nos anos subsequentes (2013 e 2016) pode estar relacionada ao fato de que eles já estariam, em certa medida, contemplados na dimensão referente à "compreensão das relações entre a escrita e as partes sonoras das palavras", o que ocorre, como pudemos observar no Quadro 2, nas edições de 2013 e 2016, nas quais aparece, por exemplo, a "produção e identificação de rimas e aliterações".

Já nos anos anteriores (1998, 2000/2001 e 2004), podemos supor que os estudos sobre consciência fonológica tenham tido pouca influência na definição dos critérios de avaliação dos livros didáticos de alfabetização, em face dos preconceitos que a teoria psicogenética da escrita tinha em relação aos estudos sobre tal dimensão metalinguística, em função da perspectiva associacionista de aprendizagem e da visão de escrita como mero código que a maioria das pesquisas - sobre consciência fonológica - adota (MORAIS, 2012, 2019b).

\section{Conhecimento das letras do alfabeto}

O conhecimento das letras do alfabeto, que constitui "[...] componente fundamental da compreensão do princípio alfabético" (SOARES, 2016, p. 209), esteve presente em diferentes edições do PNLD, sobretudo a partir de 2007, e contempla os/as seguintes conhecimentos/habilidades: diferenciação da escrita (letras) de outros sistemas de notação; reconhecimento das letras do alfabeto; exploração de diferentes tipos de letras; e exploração da caligrafia.

A diferenciação da escrita (letras) de outros sistemas de notação é um dos critérios com certa recorrência no PNLD, estando presente em quatro das seis edições analisadas, entre 2007 e 2016. Conforme dados do Quadro 4, esse/a conhecimento/habilidade contempla critérios que apresentam pouca variação ao longo dos anos, pois envolvem, basicamente, a diferenciação/distinção entre a escrita (letras) e outros sistemas de notação, que, nas duas últimas edições, são exemplificados: desenhos, números e pictogramas (como logomarcas e placas de trânsito). No PNLD 2010, aparece associado a esse critério o acréscimo "identificar que se escreve com letras" e, em 2007, há um critério próprio similar: "compreender que palavras são escritas com letras".

Práxis Educativa, Ponta Grossa, v. 16, e2117770, p. 1-22, 2021 
Quadro 4 - Critérios de avaliação do PNLD (2000/2001-2016) referentes à diferenciação da escrita (letras) de outros sistemas de notação

\begin{tabular}{|l|l|l|l|}
\hline \multicolumn{1}{|c|}{ PNLD 2007 } & \multicolumn{1}{c|}{ PNLD 2010 } & \multicolumn{1}{c|}{ PNLD 2013 } & \multicolumn{1}{c|}{ PNLD 2016 } \\
\hline $\begin{array}{l}\text { Diferenciar letras de } \\
\text { outros sinais gráficos e } \\
\text { sistemas de } \\
\text { representação. }\end{array}$ & $\begin{array}{l}\text { Diferenciar a escrita de } \\
\text { outros sistemas de } \\
\text { representação e } \\
\text { identificar que se escreve } \\
\text { com letras. }\end{array}$ & $\begin{array}{l}\text { Estabelecimento de } \\
\text { distinções entre letras e } \\
\text { outros sistemas de } \\
\text { representação (como } \\
\text { desenhos, números, } \\
\text { pictogramas }-\end{array}$ & $\begin{array}{l}\text { [As atividades] } \\
\text { promovem o } \\
\text { estabelecimento de } \\
\text { distinções entre letras e } \\
\text { outros sistemas de } \\
\text { palavras são escritas com } \\
\text { letras. }\end{array}$ \\
& & $\begin{array}{l}\text { logomarcastação (como } \\
\text { trânsito, por exemplo). } \\
\text { desenhos, números, } \\
\text { pictogramas - }\end{array}$ \\
& & & $\begin{array}{l}\text { logomarcas, placas de } \\
\text { trânsito, por exemplo)? }\end{array}$ \\
\hline
\end{tabular}

Fonte: Elaborado pelos autores. Dados da pesquisa com base em Brasil (2006, 2009, 2012, 2015).

Os critérios relativos à diferenciação da escrita (letras) de outros sistemas de notação parece também ser uma influência dos estudos sobre a psicogênese da escrita (FERREIRO; TEBEROSKY, 1985), os quais evidenciaram que, inicialmente, as crianças tendem a não distinguir entre letras, números e outros símbolos. Essa distinção, segundo as autoras, situa-se no "[...] terreno dos conhecimentos socialmente transmitidos e altamente convencionais" e, por esse motivo, "[...] sua aquisição requer condições sociais específicas (objetos e informantes à disposição)" (FERREIRO; TEBEROSKY, 1985, p. 67).

O conhecimento das letras do alfabeto aparece nas quatro últimas edições do PNLD analisadas (2007, 2010, 2013 e 2016) e contempla, como mostram os dados do Quadro 5, o/a conhecimento/identificação das letras do alfabeto, o que implica saber os seus nomes e reconhecer os seus formatos. Além disso, são as letras que materializam os fonemas e grande parte dos nomes delas contêm o som que elas representam (SOARES, 2016). A partir do PNLD 2013, explicita-se que esse conhecimento/reconhecimento se relaciona às letras em seu conjunto, em ordem sequencial, em palavras etc. No PNLD 2016, indica-se não apenas o reconhecimento de letras do alfabeto, mas também a sua escrita, o que só aparece nessa edição.

Quadro 5 - Critérios de avaliação do PNLD (2000/2001-2016) referentes ao conhecimento das letras do alfabeto

\begin{tabular}{|l|l|l|l|}
\hline \multicolumn{1}{|c|}{ PNLD 2007 } & \multicolumn{1}{|c|}{ PNLD 2010 } & \multicolumn{1}{c|}{ PNLD 2013 } & \multicolumn{1}{c|}{ PNLD 2016 } \\
\hline $\begin{array}{l}\text { Conhecer letras do } \\
\text { alfabeto. }\end{array}$ & $\begin{array}{l}\text { Conhecer as letras do } \\
\text { alfabeto. }\end{array}$ & $\begin{array}{l}\text { Conhecimento das letras } \\
\text { do alfabeto (em seu } \\
\text { conjunto, em ordem } \\
\text { sequencial, em palavras } \\
\text { etc.). }\end{array}$ & $\begin{array}{l}\text { [As atividades] contemplam } \\
\text { O reconhecimento e escrita } \\
\text { das letras do alfabeto (em } \\
\text { seu conjunto, em ordem } \\
\text { sequencial, em palavras } \\
\text { etc.)? }\end{array}$ \\
\hline & $\begin{array}{l}\text { Identificar letras em } \\
\text { diversas posições na } \\
\text { palavra. }\end{array}$ & & \\
\hline
\end{tabular}

Fonte: Elaborado pelos autores. Dados da pesquisa com base em Brasil (2006, 2009, 2012, 2015).

Outro/a conhecimento/habilidade muito recorrente na avaliação dos/das livros/coleções de alfabetização relaciona-se à exploração dos diferentes tipos de letras, cujo domínio constitui condição para que os aprendizes leiam e escrevam com autonomia (MORAIS, 2012). Os critérios relativos a esse aspecto envolvem, de modo geral, o conhecimento/reconhecimento e - no PNLD 2007 - a utilização de diferentes tipos de letras, conforme indicado no Quadro 6. Nos PNLD 2007, 2010 e 2016, salienta-se que esse conhecimento/reconhecimento das letras e a sua utilização deveriam ocorrer ou estar de acordo com situações ou contextos de uso diversos, o que parece indicar uma tentativa de impulsionar os livros didáticos a não tratarem os diferentes tipos de letras de maneira descolada das situações ou contextos sociais e culturais nas quais eles são utilizados.

Práxis Educativa, Ponta Grossa, v. 16, e2117770, p. 1-22, 2021

Disponível em: < https://www.revistas2.uepg.br/index.php/praxiseducativa $>$ 
O ensino da escrita alfabética nos critérios de avaliação do PNLD (1998-2016): Que conhecimentos...

Quadro 6 - Critérios de avaliação do PNLD (2000/2001-2016) referentes à exploração de diferentes tipos de letra

\begin{tabular}{|c|c|c|c|c|c|}
\hline $\begin{array}{c}\text { PNLD } \\
2000 / 2001\end{array}$ & PNLD 2004 & PNLD 2007 & PNLD 2010 & PNLD 2013 & PNLD 2016 \\
\hline $\begin{array}{l}\text { Exploração de } \\
\text { diferentes tipos } \\
\text { de letra. }\end{array}$ & $\begin{array}{l}\text { Exploração dos } \\
\text { diferentes tipos } \\
\text { de letra. }\end{array}$ & $\begin{array}{l}\text { Familiarizar-se } \\
\text { com diferentes } \\
\text { tipos de letras. } \\
\text { Utilizar } \\
\text { diferentes tipos } \\
\text { de letras, de } \\
\text { acordo com a } \\
\text { situação de uso. }\end{array}$ & $\begin{array}{l}\text { Reconhecer } \\
\text { diferentes tipos } \\
\text { de letra, em } \\
\text { diferentes } \\
\text { situações de } \\
\text { uso. }\end{array}$ & $\begin{array}{l}\text { Conhecimento de } \\
\text { diferentes tipos de } \\
\text { letra (imprensa/ } \\
\text { cursiva, maiúscula/ } \\
\text { minúscula). }\end{array}$ & $\begin{array}{l}\text { [As atividades] } \\
\text { exploram os } \\
\text { diferentes tipos } \\
\text { de letra } \\
\text { (imprensa/ } \\
\text { cursiva, } \\
\text { maiúscula/ } \\
\text { minúscula) em } \\
\text { contextos de } \\
\text { uso diversos? }\end{array}$ \\
\hline
\end{tabular}

Fonte: Elaborado pelos autores. Dados da pesquisa com base em Brasil (2000, 2003, 2006, 2009, 2012, 2015).

A exploração da caligrafia, que apareceu apenas na edição de 2007 do PNLD, contempla o critério de avaliação "Escrever com adequada caligrafia", o que contribuiria para "[...] o desenvolvimento de uma escrita legível e eficiente (tamanho, movimento)" (BRASIL, 2007, p. 285). No Brasil, a caligrafia constitui um tabu, sendo quase sempre associada aos tradicionais métodos de alfabetização, o que pode explicar a presença desse critério em uma única edição do PNLD. Apesar desse desprestígio e de vivermos um mundo cada vez mais tecnológico, aprender a escrever com legibilidade e com mais velocidade, usando a letra cursiva, ainda constitui um objetivo a ser alcançado depois que as crianças atingem uma hipótese alfabética (MORAIS, 2012).

Os dados do já citado estudo de Leal et al. (2013) aproximam-se dos que obtivemos quanto aos conhecimentos e às habilidades relativos às letras do alfabeto. Das 26 propostas curriculares examinadas, $24(92,3 \%)$ sinalizaram a importância do conhecimento das letras no processo de alfabetização, e as orientações mais frequentes relacionavam-se aos/às seguintes conhecimentos/habilidades: "conhecer diferentes tipos de letras"; "diferenciar letras de outros símbolos"; "conhecer a ordem alfabética; e "reconhecer e nomear as letras (46,1\%).

\section{Conhecimento de estruturas silábicas}

As estruturas silábicas correspondem às diferentes formas de organização das vogais e das consoantes na constituição das sílabas das palavras. No caso da língua portuguesa, a estrutura silábica predominante é consoante + vogal $(\mathrm{CV})$, embora existam outras possibilidades de constituição das sílabas, como VC, V, CVC, CCV, CCVC, CVCC. Em todas essas estruturas, há sempre, pelo menos, uma vogal, que é o núcleo da sílaba. Conhecer diferentes estruturas silábicas constitui também condição necessária para ler e escrever palavras com autonomia, o que faz com que Soares (2016) considere que a criança só seria considerada plenamente alfabetizada após o domínio da leitura e escrita de sílabas não canônicas (CV).

A exploração de estruturas silábicas apareceu nas quatro últimas edições do PNLD analisadas $(2007,2010,2013$ e 2016), com pouca variação na formulação dos critérios, ao longo dos anos, conforme podemos observar no Quadro 7, o qual evidencia que, nas edições de 2013 e 2016, há apenas uma especificação de algumas estruturas silábicas (CV, V, CVC etc.), assim como o acréscimo "em palavras escritas".

Práxis Educativa, Ponta Grossa, v. 16, e2117770, p. 1-22, 2021 
Quadro 7 - Critérios de avaliação do PNLD (2000/2001-2016) referentes à exploração das estruturas silábicas

\begin{tabular}{|l|l|l|l|}
\hline \multicolumn{1}{|c|}{ PNLD 2007 } & \multicolumn{1}{|c|}{ PNLD 2010 } & \multicolumn{1}{c|}{ PNLD 2013 } & \multicolumn{1}{c|}{ PNLD 2016 } \\
\hline $\begin{array}{l}\text { Explorar diferentes } \\
\text { estruturas silábicas. }\end{array}$ & $\begin{array}{l}\text { Conhecer diferentes } \\
\text { estruturas silábicas. }\end{array}$ & $\begin{array}{l}\text { Análise de diferentes } \\
\text { estruturas silábicas em } \\
\text { palavras escritas (CV, V, }\end{array}$ & $\begin{array}{l}\text { [As atividades] promovem a } \\
\text { análise de diferentes estruturas } \\
\text { silábicas em palavras escritas } \\
\text { (CV, V, CVC etc.)? }\end{array}$ \\
& & & \\
\hline
\end{tabular}

Fonte: Elaborado pelos autores. Dados da pesquisa com base em Brasil (2006, 2009, 2012, 2015).

No estudo de Leal et al. (2013), as autoras constataram que as orientações vinculadas aos conhecimentos e às habilidades relacionados aos diferentes tipos de sílabas foram as menos citadas nos documentos curriculares analisados, tendo em vista que, dos 26 documentos, apenas 7 (26,9\%) contemplavam, pelo menos, alguma orientação nesse sentido. A pouca presença desse/a conhecimento/habilidade foi atribuída pelas autoras a uma tentativa de os documentos curriculares distanciarem-se dos antigos métodos silábicos de alfabetização, apesar de a exploração de sílabas e de suas diferentes estruturas continuar sendo fundamental no processo de apropriação da escrita alfabética.

\section{Compreensão do conceito de palavra e conhecimento de palavras estáveis ou formas fixas}

Neste bloco de análise, agrupamos duas categorias de conhecimentos/habilidades relativas ao conhecimento sobre palavras que parecem constituir uma tentativa de didatização da teoria da psicogênese da escrita: a compreensão do conceito de palavra e a exploração de palavras estáveis ou formas fixas. Com relação à compreensão do conceito de palavra, trata-se, a nosso ver, de uma didatização equivocada, já que, além de constituir uma noção complexa e controversa, é a aprendizagem da escrita que permite ao aprendiz, progressivamente, tratar as palavras como unidades (FERREIRO, 2003; TEBEROSKY; COLOMER, 2003).

Esse/a conhecimento/habilidade aparece em apenas duas edições seguidas do PNLD (2007 e 2010), como podemos observar no Quadro 8. Quando observamos o detalhamento desse critério, percebemos que, em ambas as edições, o desenvolvimento do conceito de palavra está associado ao "[...] domínio da segmentação de frases em palavras e vocábulos por meio de espaços em branco" (BRASIL, 2007, p. 286). No entanto, no PNLD 2007, aparece uma menção ao "[...] desenvolvimento do conceito de palavra, em suas dimensões sintática, morfológica e semântica" (BRASIL, 2007, p. 286), o que é suprimido em 2010, provavelmente por conta do considerável grau de complexidade que essa habilidade pressupõe.

Quadro 8 - Critérios de avaliação do PNLD (2000/2001-2016) referentes à compreensão do conceito de palavra

\begin{tabular}{|l|l|}
\hline \multicolumn{1}{|c|}{ PNLD 2007 } & \multicolumn{1}{|c|}{ PNLD 2010 } \\
\hline Desenvolver o conceito de palavra. & Desenvolver a noção de palavra escrita. \\
$\begin{array}{l}\text { Desenvolver critérios para a definição do que é passível } \\
\text { de ser uma palavra escrita. }\end{array}$ & \\
\hline
\end{tabular}

Fonte: Elaborado pelos autores. Dados da pesquisa com base em Brasil (2006, 2009).

No caso da exploração das palavras estáveis ou formas fixas - que são aquelas com as quais o aprendiz tem contato frequente (nome próprio, nomes de colegas etc.) e, por isso, consegue reconhecê-las globalmente - trata-se de didatização da teoria da psicogênese da escrita que constitui quase um consenso entre os que ensinam e pesquisam alfabetização inspirados por perspectivas construtivistas (MORAIS, 2012, 2019b) e que, lamentavelmente, foi ignorada pela Base Nacional Comum Curricular (BNCC) instituída em nosso país em 2017 (MORAIS; SILVA; NASCIMENTO, 2020). No âmbito do PNLD, a exploração desse/a conhecimento/habilidade

Práxis Educativa, Ponta Grossa, v. 16, e2117770, p. 1-22, 2021 Disponível em: <https://www.revistas2.uepg.br/index.php/praxiseducativa> 
O ensino da escrita alfabética nos critérios de avaliação do PNLD (1998-2016): Que conhecimentos...

aparece explicitamente apenas na edição de 2007 do PNLD.

\section{Conhecimento de regras e irregularidades ortográficas e de outras convenções da escrita}

O conhecimento de regras e irregularidades ortográficas é uma dimensão que aparece com certa recorrência nas edições do Guia, pois esteve presente na maior parte das edições analisadas (apenas nas edições de 2007 e 2000/2001 não observamos esse aspecto). Os critérios referentes a esse conhecimento aparecem no Quadro 9.

Quadro 9 - Critérios de avaliação do PNLD (2000/2001-2016) referentes ao conhecimento da ortografia

\begin{tabular}{|c|c|c|c|}
\hline PNLD 2004 & PNLD 2010 & PNLD 2013 & PNLD 2016 \\
\hline $\begin{array}{l}\text { Consideração das } \\
\text { regularidades e } \\
\text { irregularidades } \\
\text { ortográficas. }\end{array}$ & $\begin{array}{l}\text { Escrever com domínio } \\
\text { progressivo da } \\
\text { ortografia }\end{array}$ & $\begin{array}{l}\text { Considere a criação de } \\
\text { condições para o trabalho } \\
\text { com: } \\
\text { - } \quad \text { Relações biunívocas } \\
\text { entre sons e grafemas. } \\
\text { - } \quad \begin{array}{l}\text { Relações que dependem } \\
\text { do contexto. }\end{array} \\
\text { - } \quad \text { Regularidades } \\
\text { ortográficas } \\
\text { relacionadas à } \\
\text { morfossintaxe. } \\
\text { - Irregularidades } \\
\text { ortográficas. } \\
\text { - Recurso ao dicionário } \\
\text { e/ou outras fontes para } \\
\text { solucionar problemas } \\
\text { relacionados a questões } \\
\text { ortográficas. }\end{array}$ & $\begin{array}{l}\text { [As atividades] promovem } \\
\text { o domínio das regras } \\
\text { ortográficas diretas (P, B, } \\
\text { T, D, F, V) e contextuais } \\
\text { (C-QU, G-GU, R-RR, M- } \\
\text { N-NH etc.)? }\end{array}$ \\
\hline
\end{tabular}

Fonte: Elaborado pelos autores. Dados da pesquisa com base em Brasil (2003, 2009, 2012, 2015).

A apropriação da norma ortográfica é, de fato, necessária para o domínio da língua escrita. No entanto, há uma tendência ao consenso de que, no primeiro ano do ciclo de alfabetização, a atenção deverá estar voltada à compreensão do funcionamento da escrita alfabética, sem investimento no ensino de ortografia. Esse ensino poderá ocorrer, gradativamente, quando as crianças já tiverem compreendido os princípios do sistema alfabético e dominarem razoavelmente variadas correspondências grafema-fonema, desenvolvendo mais automatismo na leitura e na escrita, além do gosto por ler e escrever (SILVA; MORAIS, 2005).

No PNLD 2004, no qual aparece o amplo critério "consideração das regularidades e irregularidades ortográficas", esperava-se, como observam Albuquerque e Ferreira (2019), que as crianças, ao término da antiga $1^{a}$ série, já soubessem ler e escrever, demonstrando, inclusive, conhecimentos ortográficos. A partir de 2010, os livros de alfabetização passaram, no contexto de um "ciclo", a ser organizados, como já dissemos, em coleções compostas por dois volumes e, em 2013 e 2016, por três volumes. Desse modo, considerando mais tempo para que o processo de alfabetização ocorra, espera-se que, ao final do ciclo, os aprendizes tenham também se apropriado de determinados conhecimentos ortográficos.

No PNLD 2010, aparece o amplo critério "Escrever com domínio progressivo da ortografia", enquanto em 2013 e 2016 são detalhadas as exigências quanto ao conhecimento de determinadas regras/irregularidades ortográficas. Se, em 2013, essas exigências eram altas, pois implicavam não apenas o domínio de regularidades diretas (relações biunívocas entre letras e sons) e contextuais, mas também de regras morfossintáticas e de irregularidades; em 2016, as expectativas

Práxis Educativa, Ponta Grossa, v. 16, e2117770, p. 1-22, 2021 Disponível em: <https://www.revistas2.uepg.br/index.php/praxiseducativa> 
parecem-nos mais adequadas ao ciclo de alfabetização de três anos, prevendo apenas o domínio de regras ortográficas diretas e contextuais, em consonância com os direitos de aprendizagem do PNAIC.

O domínio da notação alfabética pressupõe também a necessidade de apropriação de convenções da escrita que dizem respeito a unidades lexicais ou sintagmas maiores. Nesse sentido, outras convenções da escrita, além da ortografia, são encontradas nos critérios de avaliação das edições de 2004, 2007 e 2016. Tais convenções, que se referem a outras regras e normas criadas socialmente para a escrita, foram contempladas de modo bem pontual nos seguintes critérios do PNLD: "Exploração do espaçamento entre palavras e da pontuação" (PNLD 2004); "[As atividades] exploram a segmentação entre as palavras?" (PNLD 2016); e "Conhecer as direções da escrita" (PNLD 2007).

No caso da exploração da segmentação/espaçamento entre palavras, recordamos que esse aspecto foi abordado, nos PNLD 2007 e 2010, no interior do critério relativo ao desenvolvimento do conceito de palavra. Se considerarmos esse dado, a segmentação entre palavras apareceria em quatro das seis edições do PNLD.

\section{Leitura e escrita de palavras, frases e textos curtos}

Os/As conhecimentos/habilidades relativos/as à leitura de palavras, frases e textos curtos e à escrita de palavras e de frases estão voltados/as ao desenvolvimento da autonomia da criança ao ler e escrever, o que pressupõe, entre outros aspectos, o domínio das correspondências grafemafonema e fonema-grafema. Nesse sentido, ler e escrever palavras, frases e/ou textos curtos contribui para o desenvolvimento de automatismos e agilidades daqueles que estão iniciando a experiência de ler e escrever autonomamente (MORAIS, 2012).

Os conhecimentos e as habilidades avaliados/as pelo PNLD nessa categoria aparecem nos critérios elencados no Quadro 10.

Quadro 10 - Critérios de avaliação do PNLD (2000/2001-2016) referentes à leitura e à escrita de palavras, frases e textos

\begin{tabular}{|l|l|l|}
\hline \multicolumn{1}{|c|}{ PNLD 2010 } & PNLD 2013 & \multicolumn{1}{|c|}{ PNLD 2016 } \\
\hline Ler palavras. & $\begin{array}{l}\text { Leitura de palavras por meio de } \\
\text { diferentes estratégias didáticas. }\end{array}$ & $\begin{array}{l}\text { [As atividades] contemplam a leitura de } \\
\text { palavras por meio de diferentes } \\
\text { estratégias didáticas? }\end{array}$ \\
\hline Ler sentenças. & $\begin{array}{l}\text { Leitura de frases por meio de de } \\
\text { diferentes estratégias didáticas. }\end{array}$ & $\begin{array}{l}\text { [As atividades] promovem a leitura de } \\
\text { frases por meio de diferentes estratégias } \\
\text { didáticas? }\end{array}$ \\
\hline Ler textos curtos. & $\begin{array}{l}\text { Leitura de textos curtos por meio de } \\
\text { diferentes estratégias didáticas. }\end{array}$ & $\begin{array}{l}\text { [As atividades] possibilitam a leitura de } \\
\text { textos curtos por meio de diferentes } \\
\text { estratégias didáticas? }\end{array}$ \\
\hline Escrever palavras. & $\begin{array}{l}\text { Escrita de palavras por meio de de } \\
\text { diferentes estratégias didáticas. }\end{array}$ & $\begin{array}{l}\text { [As atividades] propõem a escrita de } \\
\text { palavras por meio de diferentes } \\
\text { estratégias didáticas? }\end{array}$ \\
\hline Escrever sentenças. & $\begin{array}{l}\text { Escrita de frases por meio de } \\
\text { diferentes estratégias didáticas. }\end{array}$ & $\begin{array}{l}\text { [As atividades] desenvolvem a escrita de } \\
\text { frases por meio de diferentes estratégias } \\
\text { didáticas? }\end{array}$ \\
\hline
\end{tabular}

Fonte: Elaborado pelos autores. Dados da pesquisa com base em Brasil (2009, 2012, 2015). 
Os critérios de avaliação relativos à leitura e à escrita de palavras, frases e textos curtos apareceram apenas nas três últimas edições do PNLD analisadas (2010, 2013 e 2016), o que coincide com a ampliação do ciclo de alfabetização no âmbito desse Programa. A partir da edição de 2010, tais critérios constam no eixo dos conhecimentos linguísticos, mas, na edição de 2007, eles já existiam, embora estivessem situados nos eixos de leitura/compreensão e produção de textos escritos. Consideramos que essa migração está associada a um reconhecimento de que tais habilidades estariam mais relacionadas à aprendizagem da escrita alfabética em si do que às práticas de leitura/compreensão e produção de gêneros textuais escritos.

Os critérios "Compreender que palavras podem ter a mesma quantidade de sílabas, mas não a mesma quantidade de letras e vice-versa" e "Utilizar adequadamente diferentes suportes de leitura e escrita" aparecem unicamente na edição de 2007 do PNLD e não foram incluídos em nenhuma das categorias anteriores. É curioso que tenham surgido só então e desaparecido nas edições posteriores.

\section{Considerações finais}

A análise dos critérios do PNLD referentes ao ensino da escrita alfabética, no período de 1998 a 2016, evidenciou que houve uma ampliação, ao longo dos anos, do número de critérios e dos/as conhecimentos/habilidades por eles avaliados. Nesse sentido, percebemos que as duas primeiras edições continham poucos critérios relativos a esse eixo de ensino, enquanto as seguintes apresentaram uma quantidade e detalhamento progressivamente maiores.

Compreendemos que essa ampliação parece se relacionar, por um lado, a um lento e progressivo reconhecimento da importância da "faceta linguística" da aprendizagem inicial da língua escrita (SOARES, 2016) e, por outro, à ampliação do tempo destinado à alfabetização, que passou a contemplar, a partir de 2010, além do livro do $1^{\circ}$ ano do Ensino Fundamental, os do $2^{\circ}$ e $3^{\circ}$ anos, o que implicou a consideração de outros conhecimentos e habilidades relativos ao domínio do sistema alfabético e das correspondências som-grafia.

Se, nos nove primeiros anos de existência do PNLD, pareceu evidenciar-se certa contribuição para a já mencionada "desinvenção da alfabetização", que se expressava na própria escassez de critérios que avaliassem o ensino da notação alfabética, assistimos, progressivamente, a partir de 2010, a uma busca de maior conciliação entre ensinar o sistema de escrita, ao mesmo tempo em que se insistia em assegurar ao aprendiz cuidadosas e diversificadas práticas de leitura e produção de gêneros textuais escritos, na perspectiva de alfabetizar letrando. Entendemos que os critérios de avaliação aqui examinados são historicamente marcados, refletindo, sempre, o resultado de uma negociação entre as variadas perspectivas teóricas e epistemológicas de grupos ligados ao campo acadêmico da alfabetização e ao mundo da Educação Básica, institucionalmente regido pela burocracia estatal do Ministério da Educação.

Conforme já dissemos, apesar de não pretendermos estabelecer uma relação direta e unilateral entre os critérios de avaliação do PNLD e as mudanças nos livros didáticos de alfabetização, tendo em vista que tais mudanças não se relacionam exclusivamente ao impacto do PNLD, mas também a diversos outros aspectos - como as expectativas dos professores, as orientações curriculares de diferentes âmbitos (nacional, estadual e municipal) e a dinâmica do mercado editorial -, consideramos que tais critérios impulsionaram muitas mudanças positivas nos livros didáticos de que dispúnhamos até o PNLD 2016.

A partir do Decreto No 9.099, de 18 de julho de 2017 (BRASIL, 2017), foram instituídas mudanças no Programa - algumas das quais muito polêmicas e marcadas por retrocessos -, que

Práxis Educativa, Ponta Grossa, v. 16, e2117770, p. 1-22, 2021

Disponível em: <https://www.revistas2.uepg.br/index.php/praxiseducativa> 
teve, inclusive, sua nomenclatura alterada para "Programa Nacional do Livro e do Material Didático". Aliado a isso, assistimos à exigência de obrigatoriedade da "adequação" das obras inscritas no Programa à BNCC e, mais recentemente, observamos uma tentativa de que tais obras estejam em conformidade com a Política Nacional de Alfabetização (PNA).

Os reducionismos praticados pela BNCC (MORAIS, 2020a; MORAIS; SILVA; NASCIMENTO, 2020) e pela PNA (MORAIS, 2019a) apontam a necessidade de investigarmos como, após a instituição, sem debate, desses dispositivos oficiais, os atuais livros didáticos têm conseguido manter os avanços implicados no princípio de "alfabetizar" e "letrar" simultaneamente, que vínhamos gestando e vendo crescer em nossas escolas públicas.

\section{Referências}

ALBUQUERQUE, E. B. C.; FERREIRA, A. T. B. Programa nacional de livro didático (PNLD): mudanças nos livros de alfabetização e os usos que os professores fazem desse recurso em sala de aula. Ensaio: Avaliação e Políticas Públicas em Educação, Rio de Janeiro, v. 27, n. 103, p. 250-270, 2019. DOI: https://doi.org/10.1590/s0104-40362019002701617

BARDIN, L. Análise de conteúdo. 3. ed. Lisboa: Edições 70, 2004.

BATISTA, A. A. O conceito de "livros didáticos". In: BATISTA, A. A.; GALVÃO A. M. O. (org.). Livros escolares de leitura no Brasil: elementos para uma história. São Paulo: Mercado de Letras, 2009. p. 41-73.

BATISTA A. A. G.; COSTA VAL, M. G. Livros didáticos, controle do currículo, professores: uma introdução. In: BATISTA A. A. G.; COSTA VAL, M. G. (org.). Livros didáticos de alfabetização e de português: os professores e suas escolhas. Belo Horizonte: Autêntica, 2004. p. $9-28$.

BATISTA, A. A. G.; GALVÃO, A. M. O.; KLINKE, K. Livros escolares de leitura: uma morfologia. Revista Brasileira de Educação, Rio de Janeiro, n. 20, p. 27-47, 2002. DOI: https://doi.org/10.1590/S1413-24782002000200003

BRASIL. Decreto $\mathbf{N}^{\circ} \mathbf{9 . 0 9 9}$, de 18 de julho de 2017. Dispõe sobre o Programa Nacional do Livro e do Material Didático. Brasília: Presidência da República, Casa Civil, Subchefia para Assuntos Jurídicos, [2017]. Disponível em: https://www.planalto.gov.br/ccivil_03/_ato20152018/2017/decreto/d9099.htm. Acesso em: 4 abr. 2021.

BRASIL. Decreto-Lei No 91.542, de 19 de agosto de 1985. Institui o Programa Nacional do Livro Didático, dispõe sobre sua execução e dá outras providências, [1985]. Disponível em: https://www2.camara.leg.br/legin/fed/decret/1980-1987/decreto-91542-19-agosto-1985-

441959-publicacaooriginal-1-pe.html. Acesso em: 4 abr. 2021.

BRASIL. Guia de livros didáticos: $1^{\mathrm{a}}$ a $4^{\mathrm{a}}$ série - PNLD 1998. Brasília: Ministério da Educação e do Desporto; Secretária de Ensino Fundamental, 1998.

BRASIL. Guia de livros didáticos: $1^{a}$ a $4^{a}$ série - PNLD 2000-2001. Brasília: Ministério da Educação e do Desporto; Secretária de Educação Básica, 2000.

BRASIL. Guia de livros didáticos: $1^{\mathrm{a}}$ a $4^{\mathrm{a}}$ série - PNLD 2004. Brasília: Ministério da Educação, 
O ensino da escrita alfabética nos critérios de avaliação do PNLD (1998-2016): Que conhecimentos...

Secretária de Educação Básica, 2003.

BRASIL. Guia de livros didáticos: $1^{\mathrm{a}}$ a $4^{\mathrm{a}}$ série - PNLD 2007. Alfabetização. Brasília: Ministério da Educação, Secretária de Educação Básica, 2006.

BRASIL. Guia de livros didáticos: PNLD 2010. Letramento e Alfabetização; Língua Portuguesa. Brasília: Ministério da Educação, Secretária de Educação Básica, 2009.

BRASIL. Guia de livros didáticos: PNLD 2013. Letramento e Alfabetização; Língua Portuguesa. Brasília: Ministério da Educação, Secretaria de Educação Básica, 2012.

BRASIL. Guia de livros didáticos: PNLD 2016. Alfabetização e Letramento; Língua Portuguesa: ensino fundamental anos iniciais. Brasília: Ministério da Educação, Secretária de Educação Básica, 2015.

BRASIL. Parâmetros curriculares nacionais $\left(1^{a}\right.$ a $4^{a}$ séries): Língua Portuguesa. Secretaria de Educação. Brasília: MEC/SEF, 1997.

CHARTIER, A-M. L'école et la lecture obligatoire: Histoire et paradoxes des pratiques d'enseignement de la lecture. Paris: Retz, 2007.

COSTA VAL, M. G. et al. Padrões de escolha de livros e seus condicionantes: um estudo exploratório. In: BATISTA A. A. G.; COSTA VAL, M. G. (org.). Livros didáticos de alfabetização e de português: os professores e suas escolhas. Belo Horizonte: Ceale; Autêntica, 2004. p. 75-114.

COSTA VAL, M. G.; CASTANEIRA, M. L. Cidadania e ensino em livros didáticos de alfabetização e de língua portuguesa (de $1^{\mathrm{a}}$ a $4^{\mathrm{a}}$ série). In: COSTA VAL, M. G.; MARCUSCHI, B. (org.). Livros didáticos de língua portuguesa: letramento e cidadania. Belo Horizonte: Autêntica, 2005. p. 147-184.

FERREIRA, A. T. B. et al. Livros de alfabetização: como as mudanças aparecem? In: COSTA VAL, M. G. (org.). Alfabetização e língua portuguesa: livros didáticos e práticas pedagógicas. Belo Horizonte: Ceale; Autêntica, 2009. p. 27-48.

FERREIRO, E. Escrita e oralidade: unidades, níveis de análise e consciência metalinguística. In: FERREIRO, E. (org.). Relações de (in)dependência entre oralidade e escrita. Porto Alegre: Artmed, 2003. p. 139-157.

FERREIRO, E.; TEBEROSKY, A. Psicogênese da língua escrita. Porto Alegre: Artes Médicas, 1985.

FRADE, I. Des supports pédagogiques pour apprendre à lire dans le Brésil post-colonial: héritages et innovations (1840-1960). Histoire de l'éducation, [s. l.], n. 138, p. 69-94, 2013. DOI: https://doi.org/10.4000/histoire-education.2656

GOIGOUX, R. Lire et écrire. Rapport de recherche. Étude de l'influence des pratiques d'enseignement de la lecture et de l'ecriture sur la qualité des premiers apprentissages. Lyon: Université de Lyon, 2016. Disponível em: http://ife.enslyon.fr/ife/recherche/lireecrire/rapport/rapport-lire-et-ecrire. Acesso em: 20 mar. 2021. 
LAVILLE, C.; DIONNE, J. A construção do saber: manual de metodologia da pesquisa em ciências humanas. Porto Alegre: Artmed; Belo Horizonte: Editora UFMG, 1999.

LE GOFF, J. História e memória. São Paulo: Editora Unicamp, 1996.

LEAL, T. F. et al. Reflexões sobre o ensino do sistema de escrita alfabética em documentos curriculares: implicações para a formação de professores. Olhares, Guarulhos, v. 1, p. 69-99, 2013. DOI: $\underline{\text { https://doi.org/10.34024/olhares.2013.v1.151 }}$

MONTEIRO, S. M. Exercícios para compreender o sistema de escrita nos livros de alfabetização. In: BATISTA A. A. G.; COSTA VAL, M. G. (org.). Livros didáticos de alfabetização e de português: os professores e suas escolhas. Belo Horizonte: Ceale; Autêntica, 2004. p. 201-238.

MORAIS, A. G. de. Alfabetização e letramento na BNCC: problemas conceituais, lacunas e inadequações no que é prescrito para os dois anos iniciais do ensino fundamental. Debates em Educação, Maceió, v. 12, p. 1-16, dez. 2020a. DOI: https://doi.org/10.28998/2175$\underline{6600.2020 \mathrm{v} 12 \mathrm{nEspp} 01-16 .}$

MORAIS, A. G. de. Análise crítica da PNA (Política Nacional de Alfabetização) imposta pelo MEC através de decreto em 2019. Revista Brasileira de Alfabetização, Florianópolis, v. 1, n. 10 (ed. esp.), p. 66-75, jul./dez. 2019a. https://doi.org/10.47249/rba.2019.v1.357

MORAIS, A. G. Consciência fonológica na Educação Infantil e no ciclo de alfabetização. Belo Horizonte: Autêntica, 2019b.

MORAIS, A. G. O que os novos livros didáticos de alfabetização propõem para que os aprendizes se apropriem do sistema de escrita alfabética? In: BUNZEN, C. (org.). Livro didático de Português: políticas, produção e ensino. São Carlos: Pedro \& João Editores, 2015. p. 239-264.

MORAIS, A. G. Sistema de escrita alfabética. São Paulo: Melhoramentos, 2012.

MORAIS, A. G.; ALBUQUERQUE, E. B. C. Novos livros de alfabetização: dificuldades em inovar o ensino do sistema de escrita alfabética. In: COSTA VAL, M. G.; MARCUSCHI, B. (org.). Livros didáticos de língua portuguesa: letramento e cidadania. Belo Horizonte: Ceale; Autêntica, 2005. p. 205-236.

MORAIS, A. G.; SILVA, A.; NASCIMENTO, G. S. Ensino da notação alfabética e práticas de leitura e escrita na educação infantil: uma análise das três versões da Base Nacional Comum Curricular. Revista Brasileira de Educação, Rio de Janeiro, v. 25, p. 1-25, 2020.

SILVA, A.; MORAIS, A. G. Ensinando ortografia na escola. In: SILVA, A.; MORAIS, A. G. de; MELO K. L. R. (org.). Ortografia na sala de aula. Belo Horizonte: Autêntica, 2007. p. 61-76.

SILVA, C. R. Formas de uso dos novos livros de alfabetização: por que os professores preferem os métodos tradicionais? In: COSTA VAL, M. G.; MARCUSCHI, B. (org.). Livros didáticos de língua portuguesa: letramento e cidadania. Belo Horizonte: Ceale; Autêntica, 2005. p. 185-203.

SILVA, C. S. R. Princípios metodológicos em livros de alfabetização aprovados no PNLD 2007. In: COSTA VAL, M. G. (org.). Alfabetização e língua portuguesa: livros didáticos e práticas pedagógicas. Belo Horizonte: Ceale; Autêntica, 2009. p. 49-66. 
O ensino da escrita alfabética nos critérios de avaliação do PNLD (1998-2016): Que conhecimentos...

SOARES, M. Alfabetização: a questão dos métodos. São Paulo: Contexto, 2016.

SOARES, M. Letramento e alfabetização: as muitas facetas. Revista Brasileira de Educação, Rio de Janeiro, n. 25, p. 5-17, jan./abr. 2004. DOI: http://dx.doi.org/10.1590/S1413$\underline{24782004000100002}$

TEBEROSKY, A.; COLOMER, T. Aprender a ler e a escrever: uma proposta construtivista. Porto Alegre: Artmed, 2003.

Recebido em 24/03/2021

Versão corrigida recebida em 20/05/2021

Aceito em 21/05/2021

Publicado online em 01/06/2021 